W. D. Mukhtyar, V. C. Munot, U. C. Nag, Naylor, Pauline M. Naylor, B. A. Obi, H. S O'Connor, J. E. A. Oni-Orisan, S. R. Pandit Maria-Danuta Paszkowski, P. J. Paterson, Adeline W. Patterson, Wing Foo Pau D. A. Penny, I. B
Peters. A. Prakash, J. M. Quilter, S. Qureshi. D. J Rawling, G. Sarkar. Hala Sarsam, A. SaungsomScrimgeour, A. Sen, A. A. Shah, F. Sharp, M. S Sidhu, Barbara J. Simpson, B. F. C. Smith. T. S Spencer, S. J. Steigrad, G. M. Stirrat, J. Y. Teo, Eng Soon Teoh, C. D. Venning, R. H. T Ward, P. F. Whiteley, R. H. Williams, Rosemary Williams, S. M. Wood, A. Zia.

At the meeting of the council held on 27 July, with the president, Sir John Peel, in the chair, Audrey P. Ward was appointed Blair-Bell lecturer for 1968.

The following officers were elected: president, Sir John Peel; vice-presidents, Professor T. N. A. Jeffcoate and Professor J. A. Stallworthy ; honorary treasurer, Mr. I. M. Jackson; honorary secretary, Mr. E. A. J. Alment; honorary librarian, Mr. A. L. Gunn; honorary museum curator, Mr. R. M. Haines; assistant honorary museum curator, Mr. D. W. T. Roberts ; regional council honorary treasurers: Australia, Mr. R. C. Gill ; Canada, Mr. L. J. Quinn; New Zealand, Mr. K. D. Drayton; South Africa, Mr. H. McK. G. Agnew.

\section{ROYAL COLLEGE OF SURGEONS OF ENGLAND}

At a meeting of the Council held on 1 August, with Sir Hedley Atkins, president, in the chair, the elections of Mr. B. W. Fickling, as dean, and of Professor G. L. Slack, as vice-dean of the Faculty of Dental Surgery for the year from 20 July 1968, were reported. Mr. B. W Fickling was admitted as a Member of Council representing the Faculty of Dental Surgery, hav-

\section{New Issues of Specialist Journals}

Obtainable from the Publishing Manager, B.M.A. House, Tavistock Square, London W.C.1. ABSTRACTS OF WORLD MEDICINE

The August issue (Volume 42, No. 8) contains, in addition to abstracts of papers covering a wide variety of subjects, a review article entitled

Present Position and Future Prospects in the

Management of Chronic Renal Failure

By f. R. Curtis, M.B., B.S., M.R.C.P.

The advent of intermittent haemodialysis and renal transplantation has opened up exciting new fields in the treatment of patients with chronic renal failure, though at present only a minority of patients can be treated with these techniques. Their advanages, limitations, and complications are explored fully in this paper and future plans are outlined. Attention is also paid to conservative management, which still plays a very important part and which is becoming increasingly efficient, especially in the control of severe hypertension.

Published monthly. Yearly subscription £6 6s., U.S.A. \$18. Single number 12s. 6d.

\section{BRITISH JOURNAL OF OPHTHALMOLOGY}

Contents of the August issue are as follows

Reis-Bücklers' Dystrophy. N. S. C. Rice, N. Ashton, B. Jay, and R. K. Blach.

Influence of pH on the Effect of Pilocarpine on Aqueous Dynamics. R. A. Anderson and J. B. Cowle.

Influence of pH on the Effect of Pilocarpine on Aqueous Dynamics. R. A.
Surgical Correction of Certain Lacrimal Passage Anomalies. W. J. Levy.

Surgical Correction of Certain Lacrimal Passage Anomalies. W. J. Lev
Adrenergic Blocking Agents. A. L. Crombie and A. A. H. Lawson.
Approach to Orbital Tumours. P. Sivasubramaniam.

Aataract Extraction in a Case of Congenital Coloboma of the Iris. D. H. Nixseaman.

Congenital Corneal Opacities with Reiger's Anomaly and Down's Syndrome. A. J. Dark and T. H. Kirkham.

Sphenoidal Ridge Meningioma with Optic Nerve Metastasis. C. E. Moore.

Colour Vision of Two Albinos. R. W. Pickford and W. O. G. Taylor.

Volume 52 , No. 8. Yearly subscription (12 numbers) inland $£ 88$ s., overseas $£ 9$. With Ophthalmic Literature and Index (7 numbers) inland $£ 15$, overseas $£ 16$.

\section{ARCHIVES OF DISEASE IN CHILDHOOD}

Contents of the August issue are as follows:

Review Article

Disorders of the Serum Lipoproteins. I. Lipoprotein Deficiency States. June K. Lloyd.

In Vivo Penetration of Antibiotics into Sputum in Cystic Fibrosis. B. A. Saggers and David Lawson. valuation of Deficiency of 21-Hydroxylation in Patients with Cong

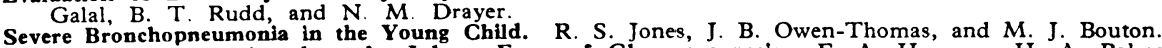
Leigh's Encephalomyelopathy : An Inborn Error of Gluconeogenesis. F. A. Hommes, H. A. Polman, and J. D. Reerink.

Detrusor Action in Children with Myelomeningocele. D. W. G. Cooper.

actose Intolerance in Childhood Coeliac Dis

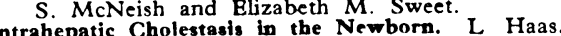

Thymic Alymphoplasia, Monoclonal Gammopathy, and Pneumocystis Carinil Pneumonia in an Infant. ymic Alymphoplasia, Monoclonal G. M. O. Becroft and R. Douglas.
D. M.

Streptococcal Bacteraemia in Children Following Dental Extractions. R. H. Elliott and J. M. Dunbar.

Early Diagnosis of Familial Dysautonomia. Case Report with Special Reference to Primary Pathophysiological Pindings. Janet Goodall, Elliot Shinebourne, and Brian D. Lake.

Serum Siderophilin in Kwashiorkor. A U. Antia, $H$. McFarlane, and J.F. Soothill.

Toasted Full-fat Soya Flour in Treatment of Kwashiorkor. Ingrid H E. Rutishauker and B. A. Wharton. Ureteric Reflux and Kidney Scarring in Children. John E. S. Scott and J. M. Stansfeld.

Further Observations on Serum Proteins to Respiratory Distress Syndrome of the Newborn. Gwendoline

Hardie, V. C. Harrison, and J. E. Kench.
Plasma Renin and Angiotensinogen Levels in Pathological States Associated with Oedema. Masashi Imai and Hirofumi Sokabe.

Fatal Infectious Mononucleosis with Liver Failure in Two Sisters. J. T. Harries and A. W. Ferguson.

Ventilating the Lungs of Newborn Iniants for Prolonged Periods. M. E. Tunstall, J. I. Cater, Jean S

Paediatric Pathology Society. Proceedings of the Thirteenth Annual Meeting.

Correspondence. Bonk Reviews.

Vohume 43, No. 230 . Yearly subscription (6 numbers) $£ 44$ s.s abroad $£ 415 s$. ing been elected to this office by the Board of Faculty.

The deaths of Sir Henry Dale, O.M., F.R.S. (Honorary Fellow, Honorary Fellow in the Facuity of Anaesthetics, Member of the Court of Patrons, and a Past Trustee of the Hunterian Collection), and of Dr. Charles Mayo (Honorary Fellow) were reported with deep regret.

The appointment of Mr. A. G. Leigh (Moorfields Eye Hospital) as the Pocklington Memorial lecturer for 1969 , and the appointment of Dr. B. H. Crawford (Imperial College of Science and Technology) as the EdridgeGreen lecturer for 1968, were reported.

The Handcock prize was awarded to R. J.

Horton (St. Bartholomew's Hospital Medical School).

A diploma of Fellowship was granted to A. J. Bron.

Diplomas of membership were granted to J. M. De Capua, Carol J. Higgins, B. W. R. Moore, P. A. M. Raine, and R. D. Spicer.

\section{Correction}

The leading article on "Prevention of Rubella Malformations" (27 July, p. 199) stated in the last sentence of the third paragraph that "it is hard to escape the fact that the reported incidence of defects of the rubella type was lower in children whose mothers had been given a moderate dose of immunoglobulin than in those who had not." What it should have said was that "the reported incidence of defects of the rubella type was lower in children whose mothers had been given a moderate dose of immunoglobulin, and who had escaped infection, than in those who contracted clinical disease."

\section{Notice to Authors}

When original articles and letters for publication are not submitted exclusively to the British Medical fournal this must be stated.

Correspondence on editorial business should be addressed to the Editor, British Medical Fournal, B.M.A. House, Tavistock Square, London W.C.1, Telephone: 01-387 4499. Telegrams: Aitiology, London W.C.1.

Authors wanting reprints of their articles should notify the Publishing Manager, B.M.A. House, Tavistock Square, W.C.1, on receipt of proofs.

\section{Subscriptions}

Members' subscriptions should be sent to the Secretary of the British Medical Association, B.M.A. House, London, or to the Scottish Secretary, B.M.A. Scottish Office, Drumsheugh Gardens, Edinburgh.

Doctors who are not members of the B.M.A. can subscribe to the B.M.F. The rates for doctors resident in the United Kingdom and abroad are given on the first page of the classified advertisements. These include the rates for the Australian edition and the North American "Air Express," which are available to both members and non-members of the B.M.A.

\section{Classified Advertisements}

Doctors Abroad.-Copies of the appointment vacancies advertised in the B.M.F. can be sent by airmail on request. The minimum cost is $3 \mathrm{~s}$ per week, for which copies of vacancies in up to five sections of the classified advertisements will be sent. The cost of each further section after five is $1 \mathrm{~s}$. Orders for specific grades in any section cannot be accepted. Payments should be enclosed with the order.

Details of rates, etc., for classified advertisements appear on the first page of the classified section. 